\title{
FINITE-DIMENSIONAL VECTOR SPACES
}

\author{
PAUL R. HALMOS \\ Professor of Mathematics
}

The University of Michigan

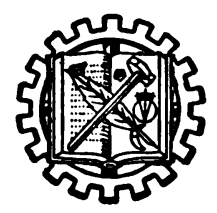

$\overline{\text { SECOND EDITION }}$

\section{VAN NOSTRAND COMPANY, INC.}

PRINCETON, NEW JERSEY

NEW YORK 